\title{
KONSEP PEMIKIRAN PENDIDIKAN ISLAM KONTEMPORER DI INDONESIA
}

\author{
Rusli Malli ${ }^{1}$ \\ Pendidikan Agama Islam Fakultas Agama Islam| Unismuh Makassar
}

\begin{abstract}
ABSRAK
Munculnya fenomena paham keislaman yang amat beragam, tentunya memilki latar belakang kemunculannya, batasan dan ciri-ciri dari masing-masing gerakan pemikiran Islam yang muncul di Indonesia. Masing-masing mempunyai corak dan wajah yang cukup beragama. Dari corak tersebut perlu diketahui dan dipelajari. Adapun jenis penelitian ini adalah kajian pustaka dengan menggunakan pendekatan sosiologi Agama dan sejarah yang akan mengungkap beberapa konsep pemikiran Islam kontemporer di Indonesia. Perkembangan pemikiran islam di Indonesia semakin berkembang dengan lahirnya beberapa tokoh-tokoh pemikirin islam diantaranya K. H. Ahmad Dahlan, Abdur Rahman Wahid (Gus Dur), Nur Khalid Majid, Fazlur Rahman, Muslim Hassan Hanafi, Adonis, Mahmud Muhammad Thaha, Nash Hamid Abu Zaid, Muhammad Syahrur, dengan berbagai pemikiran yang berbeda-beda. Adapun perkembangan dan konsep pemikiran Islam di Indonesia ada empat (4) yaitu: 1. Pemikiran Islam Fundamentali. 2. Neo Tradisionalis. 3. Neo Modernis. dan 4. Liberalis.
\end{abstract}

\section{Kata Kunci: Konsep Pemikiran Islam, Pendidikan Kontemporer}

\begin{abstract}
The emergence of the phenomenon of Islamic understanding are very diverse, of course, have the background of its emergence, extent and characteristics of each movement of Islamic thought which emerged in Indonesia. Each has a complexion and facial pretty religious. Based the feature needs to be known and studied. The type of this research is literature review using a sociological approach to religion and history that will reveal some of the concepts of contemporary Islamic thought in Indonesia. The development of Islamic thought in Indonesia is growing with the birth of some of the figures Islamic thought among KH. Ahmad Dahlan, Abdur Rahman Wahid (Gus Dur), Nur Khalid Majid, Fazlur Rahman, Muslim Hassan Hanafi, Adonis, Mahmoud Muhammad Taha, Nash Hamid Abu Zaid, Muhammad Shahrur, with a variety of different ideas. The development and the concept of Islamic thought in Indonesia there are four (4): 1. Islamic Thought Fundamentally. 2. Neo Traditionalist. 3. Neo Modernists and 4. Liberals.
\end{abstract}

Keywords: Concepts Of Contemporary Islamic, Contemporer Of Education 


\section{PENDAHULUAN}

Manusia merupakan makhluk allah swt.yang sempurna sesuai dengan tugas fungsi dan tujuan penciptaannya sebagai khalifah filard dan terbaik bila di bandingkan dengan makhluklainnya. Kelebihan manusia bukan hanya sekedar berbeda susunan fisik, tapi juga lebih jauh adalah kelebihan aspek psikisnya dengan totalitas potensinya masing-masing yang sangat mendudukung bagi proses aktualitas diri pada posisinya sebagai makhluk mulia. Integritas kedua unsur tersebut abersifat aktif dan dinamis sesuai dengan perkembangan dan tuntunan zaman di mana manusia berada.dengan potensinya material dan spiritual tersebut,menjadikan manusia sebagai makhluk ciptaan allah swt.yang terbaik.secara sistematis pada proposisinya pengetahuan yang di miliki peserta didik maka,pendidikan harus mampu mengarahkan peserta didik pada pengembangan diri secara totaliras.islam dengan ajaran yang universal tidak menghendaki adanya sistem pendidikan yang dikotomik parsial dalam menempatkan peserta didik baik teoritis maupun praktis peserta didik manawarkan sistem pensisikan yang integral dan mengempatkan sesuai dengan tuntutan yang di gariskan oleh allah swt. Dalam penjelasan tersebut di atas penulis akan mengkolaborasikan kajian secara mendalam tentang Pemikiran pendidika Islam di Indonesia. Batasan masalah secara umum yaitu: Bagaimana konsep pemikiran pendidikan islam di Indonesia.

\section{HASIL DAN PEMBAHASAN}
A. Pengertian Pendidikan Islam

Secara etimologi pemikiran berasal dari kata dasar pikir,berarti proses,cara atau perbuatan memikir yaitu menggunakan akal budi untuk memutuskan suatu persoalan dengan mempertimbangkan segala sesuatu secara bijaksana.Dalam konteks ini pemikiran dapat di artikan sebagai upaya cerdas (ijtihady) dari proses kerja akal dan kalbu untuk melihat fenomena dan berusaha mencari penyelesaiannya secara bijaksana sedangkan pendidikan ,secara umum berarti sesuatu proses perubahan sikap dan tingkah laku seseorang atau sekelompok orang (peserta didik) dalam usaha mendewasakan manusia (peserta didik) ,melalui upaya pengajaran dan latihan .serta proses perbuatan dan cara-cara mendidik.Dengan berpijak pada definsi di atas maka yang dimaksud dengan pemikiran pendidikan islam adalah proses kerja akal dan kalbu yang dilakukan secara bersungguh-sungguh dalam melihat berbagai persoalan yang ada dalam pendidikan islam dan berupaya untuk membangun sebuah peradaban pendidikan yang mampu menjadi wahana bagi pembinaan dan pengembangan peserta didik secara paripurna.

\section{B. Sekilas Sejarah Pendidikan Islam}

Sejarah pendidikan sama usianya dengan sejarah manusia itu sendiri.keduanya tak dapat dipisahkan antara satu dengan yang lain. Manusia tidak akan bisa berkembang secara sempurna bila tidak ada pendidikan untuk itu tidak berlebihan jika dikatakan bahwa eksistensi pendidikan merupakan salah satu syarat yang mendasar bagi meneruskan dan mengekalkan kebudayaan nmanusia. 
Di sini, fungsi pendidikan berupaya menyesuaikan kebudayaan lama dengan kebudayaan baru secara propesional dan dinamis. Wacana pemikiran pendidikan Islam masa nabi sudah tentu tidak sesistimatis dan secanggih yang ada sekarang ini. Meskipun demikian perhatian ummat terhadap ilmu pebgetahuan jelas sangat tinggi dan hal ini terwjud sesuai dengan kemungkinan kondisi sosial waktu itu. Ketika di Mekkah, proses pendidikan Islam dilakukan nabi dan para pengikutnya Dar Al-Arqam, sebagai pusat pendidikan dan dakwah. Setidaknya ada empat alasan pentingnya pelacakan pendidikan dan sesudahnya, yaitu : pertama, dalam tatanan Kehidupan masyarakat yang dinamis, ada upaya pewarisan nilai kebudayaan antara generasi tua kepada generasimuda, bahkan pendidikan seringkali di jadikan tolak ukur layak atau tidaknya manusia menduduki dan melaksanakan amanat Allah sebagai khalifah fi al-ardh. Sebagaimana firman Allah SWT

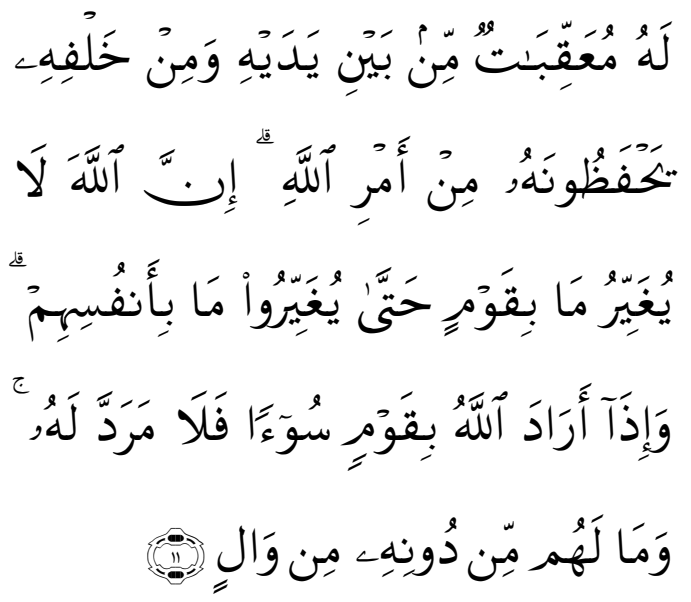

Terjemahan:

"(767) Bagi manusia ada malaikatmalaikat yang selalu mengikutinya bergiliran, di muka dan di belakangnya, mereka menjaganya atas perintah AllahSesungguhnya Allah tidak merobah keadaan sesuatu kaum sehingga mereka merobah keadaan, (768) yang ada pada diri mereka sendiri. dan apabila Allah menghendaki keburukan terhadap sesuatu kaum, Maka tak ada yang dapat menolaknya; dan sekali-kali tak ada pelindung bagi mereka selain Dia." (Departemen Agama)

Munculnya dinamika pembaharuan pemikiran pendidikan yang dilakukan sejumlah intelektual muslim dari masa ke masa, tidak terlepas dari kondisi objektif sosialbudaya dan sosial keagamaan umat Islan itu sendiri. Oleh karena itu, tidak berlebihan jika di katakan, bahwa dinamika pemikiran intelektual muslim merupakan hasil refleksi terhadap kondisi umat Islam pada zamannya. Sederetan intelektual muslim, sejak masa awal sampai pada era posmodernisme telah berupaya merekonstruksi guna terciptanya sistem pendidikan Islam yang ideal. Kelompok intelektual muslim tersebut antara lain adalah :

1. Ibnu Maskawih (Ahmad Ibnu Muhammad ibnu Ya'qub ibnu Miskawih), lahir di Rayy sekitar 320 H / 432 M. Dan meninggal di Isfaham pada tanggal 9 safar buwaihi yang berlatar belakang mazhab syi' ah. Perhatiannya dalam menuntut ilmu sangat besar. Hal ini tercermin dari bidang ilmu pengetahuan yang ditekuninya. Dalam bidang sejarah umpamanya, ia belajar dengan Abu Bakar Ahmad ibn Kamil Abu Thayyib. Pemikirannya tentang pendidikan lebih berorientasi pada pentingnya pendidikan akhlak. Hal ini tercermin dari karya monunetalnya, Takzib Al-akhlak. Melalui karya 
tersebut Maskawih menyatakan bahwa tujuan pendidikan adalah terwujudnya sikap batin yang secara spontan mampun mendorong lahirnya perilaku dalam memperoleh karimah-perilaku yang sedemikian akan sangat membantu peserta didik dalam memperoleh kesempurnaan dan kabahagiaan yang sejati.

2. Ibnu Sina (Abu Ali AL-Husaiyn Ibnu Abdullah Ibnu Al-Hasan Ibnu Sina) lahir pada tahun 370 / 980 di Asyanah, Bukhara (dalam peta moderen masuknya Turkistan) ia wafat oleh penyakit disentri pada tahun 428 / 1037 dan dimakamkan di Hyamadan (sekarang dalam wilayah Iran). Hasil pemikiran dari Ibnu Sina Anataranya :
a. Falsafah wujud
b. Faksafah Faidh
c. Falsafah Jiwa

3. Ibnu Khaldum (Waliuddin Abdurrahaman bin Muhammad bin Muhammad bin Hasan bin Jobir bin Muhammad bin Ibrahim bin Andurrahaman bin Walid bin Usman) lahir di Tunisia pada tanggal 1 Ramadhan $732 \mathrm{H} / 27$ Mei 1332 M dan wafat di kairo 25 Ramadhan 808 H/ 406 M.

4. Muahammad Abdus ibn Hasan Khairuddin, lahir pada tahun 1265 H/ 1849 M. pada sebuah desa di Propinsi Gharbuyyah- ia lahir dari lingkungan petani sederhana yang taat dan sangat mencintai ilmu pengetahuan.

5. Ismail Raji Al faruqi. Lahir di Sayfa (Palestina) pada tanggal 1 januari 1921. Ia meninggal pada tanggal 1986. Latar belakang pendidikannya di tempuh pada pendidikan barat yaitu Colege Des Peres (1936). Kemudian pendidikan pasca sarjana mudanya ia rampungkan pada America University dan Harvard University (1941). Kemudian program magisternya pada Indian University dan harvard University dalam bidang filsafat, sedangkasn gelar doktor ia peroleh pada Indian University dalam bidang yang sama.

6. Syed Muhammad Waquib AlAttas dilahirkan di Bogor Jawa Barat pata tanggal 5 September 1931. Paradigma pemikiran AlAttas bila dikaji secara historis merupakan sebuah pemikiran yang berasal dari dunia metafisika kemudian kedunia kosmologis dan bermuara pada dunia psikologis, perjalanan kehidupan dan pengalaman pendidikannya memberikan andil yang sangat besar dalam pembentukan paradigma pemikiran.

\section{Pemetaan Pemikiran Islam Kontemporer Di Indonesia}

Munculnya fenomena paham keislaman yang amat beragam, tentunya memilki latar belakang kemunculannya, batasan dan ciri-ciri dari masing-masing gerakan pemikiran Islam yang muncul di Indonesia. Masing-masing mempunyai corak dan wajah yang cukup beragama. Berikut ini dikemukakan diantara corak pemikiran gerakan Islam kontemporer.

\section{Islam Fundamentalis}

Istilah Islam fundamentalis dapat dimaknai Islam yang dalam pemahaman dan prakteknya bertumpu pada ha-hal yang bersifat asasi atau mendasar. Pemahaman secara kebahasaan yang demikian ini 
mengandung pengertian, bahwa yang dimaksutkan Islam fundamentalis adalah gerakan atau paham yang bertumpu pada ajaran mendasar dalam Islam, teutama terkait dengan rukun Islam dan Iman. Apabila ditinjau dari segi kebahasaan ini, maka semua aliran atau paham yang menjadikan rukun Iman dan Islam sebagai ajaran utama, maka mereka termasuk pada kelompok ini. Bahkan tiga aliran besar di dunia, seperti Sunni, Syi'ah dan Ahmadiyah juga menjadikan ajaran tersebut sebagai dasar pijakan dalam beragama. Disamping itu dalam konteks Indonesia, dua paham keagamaan terbesar, seperti NU dan Muhammadiyah pun juga termasuk dalam pengertian kebahasaan ini. Namun, persoalannya tidak semudah itu untuk memasukkan beberapa kelompok paham keagamaan dalam Islam fundamentalis, karena harus dilihat ciri-ciri dan ajaran pokok dalam gerakannya.

Sebenarnya istilah ini muncul dikalangan masyarakat Kristen yang berkembang di Barat, yang dalam hal pemahaman agamanya lebih bersifat mendasar, sempit dan dogmatis. Di Barat, kelompok ini muncul sebagai reaksi terhadap teori evolusi manusia yang dikemukakan oleh Charles Darwin. Dikalangan dunia Islam, istilah fundamentalis lebih ditujukan kepada kelompok Islam garis keras. Pengertian kaum fundamentalis, dari segi istilah bahkan akhirnya memiliki muatan psiokologis dan sosiologis, dan berbeda dengan pengertian fundamentalis secara kebahasaan. Pada masyarakat Muslim, istilah ini, ada kaitannya dengan masalah pertentangan politik, sosial, politik dan kebudayaan. Istilah fundamentalisme ini pada akhirnya menimbulkan citra tertentu, yaitu ekstrimisme, fanatisme, atau bahkan terorisme dalam mewujudkan atau mempertahankan keyakinan agamanya, bahkan mereka ini cenderung melakukan tindakan kekerasan.

\section{Islam Neo-Tradisionalis}

Dalam konteks pemikiran Islam Indonesia, sebelum munculnya istilah pemikiran neo-tradisionalisme adalah munculnya kelompok tradisionalis. Menurut Abudian Nata, kelompok ini awalnya ditujukan kepada mereka yang berpegang pada al-Qur'an dan asSunnah, namun kemudian juga ditujukan kepada mereka yang perpegang pada produk-produk pemikiran para ulama yang dianggap unggul dan kokoh dalam keilmuan fiqh, tafsir, teologi, tasawuf, lughah, ushul fiqh dan lainnya. Kemudian belakangan ini munculah gerakan neotradisionalis, yang digagas oleh tokoh atau kelompok yang hendak merubah paradigma berfikir tradisionalis. Istilah Neo-tradisionalis terkadang didentikkan dengan Gus Dur. Sekalipun bukanlah satu-satunya. Kenyataannya, beliau juga inspiratis dan penggiat gerakan neo-modernisme, post-tradisionalisme, bahkan Islam liberal.

Sebagai pemikiran yang bertolak dari tradisi, neo-tradsionalisme melihat bahwa Islam selaras dengan perkembangan kebudayaan lokal, sehingga sangat menghargai multikulturalisme. Neo-tradsionalisme cenderung pada kebudayaan lokal di mana Islam berkembang (living). Kebudayaan Arab juga lokal sehingga Islam Arab semata-mata merupakan ekspresi kebudayaan orang Arab, bukan Islam itu sendiri. Di samping 
itu, cenderung berpandangan dan bersikap inklusif (terbuka) atas realitas social, sebagaimana dikemukakan Marzuki Wahid.

Dalam persolan bernegara, kelompok ini melihat bahwa Islam sama sekali tidak memiliki bentuk negara. Yang penting bagi Islam adalah etika kemasyarakatan. Alasannya, Islam tidak mengenal konsep pemerintahan yang definitif. Begitu juga dalam hal suksesi kekuasaan, Islam tidak memiliki bentuk tetap. Terkadang memakai istikhlaf, bai' at (pengangkatan), dan ahli halli wal aqdi, seperti dikemukakan Ahmad Amir Aziz, dalam bukunya Neo-Modernisme Islam Di Indonesia. Untuk itu, umat Islam Indonesia harus dapat menerima kesadaran dan wawasan kebangsaan sebagai realitas objektif dan tidak perlu dipertentangkan.

\section{Islam Neo-Modernis}

Pada awalnya, sebenarnya muncul istilah Islam modernis, yang mempunyai tujuan membawa Islam kepada agama yang berkemajuan. Seperti halnya yang berlangsung di Barat, di dunia Islam, gerakan Islam modernis ini muncul dalam rangka menyesuaikan paham-paham keagamaan Islam dengan perkembangan baru yang ditimbulkan kemajuan ilmu pengetahuan dan teknologi modern. Munculnya gerakan ini juga mewrupakan respon terhadap berbagai keterbelakangan yang dialami umat Islam dalam bidang ekonomi, pendidikan, kebudayaaan, politik dan lainnya. Keadaan yang demikian ini dirasa tidak sejalan dengan semangat ajaran Islam, yang digambarkan bahwa Islam itu mendorong kearah kemajuan, menjunjung tinggi ilmu pengetahuan,yang muaranya membawa kemaslahatan bagi kehidupan umat manusia. Namun faktanya justru umat Islam mengalami masa keterbelakngan dan kemunduran. Inilah yang memunculkan kegelisahan batin bagi para pemikir gerakan modern ini, untuk berusaha memahami ajaran Islam secara kontekstual, agar ajaran islam itu bisa terwujud dalam kehidupan masyarakat.

Kemudian, belakangan munculah istilah Islam Neo-Modernis yang kirakira mulai nampak pada era tahun 1970-an. Pada masa inilah corak pemikiran keislaman mulai dijangkiti gejala baru atau pembaruan yang belakangan disebut "neo-modernisme". Sosok Cak Nur, misalnya dianggap sebagai lokomotif pembuka bagi tergelarnya wacana neo-modernisme Islam Indonesia. Gerakan ini lebih menempatkan Islam sebagai sebuah sistem dan tatanan nilai yang harus dibumikan selaras dengan tafsir serta tuntutan zaman yang kian dinamis. Watak pemikirannya yang lebih inklusif, moderat, dan mengakui adanya kemajemukan dalam kehidupan, sehingga membentuk sikap keagamaan yang menghargai timbulnya perbedaan.

Gerakan Islam neo-modernis awalnya digagas oleh Fazlur Rahman, tokoh reformis asal Pakistan. Gerakan ini cukup dinamis, bahkan radikal baik terhadap Barat maupun Islam sendiri. Fazlur Rahman pernah mengatakan, bahwa neo-modernis harus mengembangkan sikap kritis terhadap Baratmaupun warisan-warisan kesejarahan Islam sendiri. Kaum Muslim harus mengkaji dunia Barat beserta gagasan-gagasannya maupun ajaran-ajaran dalam sejarah keagamaan Islam sendiri, bila hal ini tidak dikaji 
secara obyektif, maka keberhasilannya dalam menghadapi dunia modern merupakan suatu hal yang mustahil bahkan kelangsungan kehidupannya sebagai Muslim sangat diragukan. Gerakan ini muncul sebagai respon atas tuntutan zaman yang semakain berkembang, namun kurang diantisipasi oleh berbagai pemikiran keislaman yang mampu secara teoritis dan metodologis keislaman yang komprehensif dan rasional.

\section{Islam liberal}

Setelah gerakan Islam NeoModernis mengalami metamorfosis, nampaknya pemikiran Islam semakin berkembang seiring dengan berkembangnya model pemikiran, baik yang muncul di dunia Islam maupun di Barat. Hal ini juga yang terjadi di Indonesia, bahwa setelah lebih dari 30 tahun gerakan pemikiran model neomodernisme mendapat tempat dalam konstelasi pemikiran Islam di Indonesia, kemudian munculah gerakan "Islam liberal". Istilah ini muncul ketika Greg Barton menyebutnya dalam bukunya: Gagasan Islam Liberal di Indonesia. Kira-kira tahun 2001, publikasi mazhab pemikiran "Islam liberal" ini memang tampak digarap sistematis, yang kemudian dikelola menjadi "Jaringan Islam Liberal" (JIL).

Muhammad

Muslih menyebutkan, bahwa sebelum lahir JIL, wacana Islam liberal beredar di meja-meja diskusi dan sederet kampus, akibat terbitnya buku Islamic Liberalism (Chicago, 1988) karya Leonard Binder, dan buku Liberal Islam (Oxford, 1998) hasil editan Charles Kurzman. Istilah Islam liberal pertama dipopulerkan Asaf Ali Asghar Fyzee, intelektual muslim India, pada 1950-an. Kurzman sendiri mengaku meminjam istilah itu dari Fyzee. Geloranya banyak diprakarsai anakanak muda usia, 20-35 tahun. Untuk kasus Jakarta, mereka umumnya para mahasiswa, peneliti, atau jurnalis yang berkiprah di beberapa lembaga, semisal Paramadina, Lembaga Kajian dan Pengembangan Sumber Daya Manusia Nahdlatul Ulama (Lakpesdam NU. Gerakan Islam Liberal ini tentu saja banyak mendapatkan kritikan dari berbagai pihak, teruatama bagi mereka yang ingin tetap menjaga ajaran Islam dari pengaruh paham-paham Barat yang cenderung liberal dalam memahami teks agama. Pemikiran Islam Liberal telah dianggap menodai ajaran islam, karena kitab suci dianggap sebagai produk budaya, sehingga sakralitasnya pun menjadi nihil.

\section{KESIMPULAN}

Dari uraian diatas dapat kita simpulkan : Pemikiran pendidikan Islam adalah serangkaian proses kerja akal dan kalbu secara bersungguhsungguh dalam melihat berbagai persoalan yang ada dalam pendidikan Islam, Sejarah pemikiran Islam dimulai pada masa Nabi Muhammad dan merupakan masa pembinaan dan Corak pemikiran islam di Indonesia semakin berkembang sesuai dengan kondisi zaman yang semakin mangantar manusia untuk berpikir lebih dinamis.

\section{DAFTAR PUSTAKA}

Nata, Abuddin, Pemikiran Para Tokoh Pendidikan Islam, PT. Raja Grapindo Persada, Jakarta arta, 2003 
Daudy, Ahmad, Segi-segi Pemikiran

Falsafi dalam Islam, Bulan

Bintang, Jakarta, 1984

Susanto. A. Pemikiran Islam, Amzah, Jakarta , 2009

Sanaky Hujair AH, Paradigma Pendidikan Islam Safiria Insani Press Yogyakarta, 2003

Soebahar, Abd. Halim, Wawasan Baru Pendidikan Islam, Kalam Mulia, Jakarta, 2002

Langgulung, Hasan, Pendidikan Islam Dalam Abad Ke-21, Pustaka alHusna Baru, Jakarta, 2003. 